\title{
HUBUNGAN TINGKAT PENGETAHUAN DAN PERAN PETUGAS KESEHATAN DENGAN PERILAKU BABS DI DESA KALIANGET SERIRIT BULELENG
}

\author{
Kadek Nur Pita Sari ${ }^{1}$, I Wayan Sudiadnyana ${ }^{2}$
}

\begin{abstract}
The public habit of open defecation is one of the habits that individuals have as a result of imitating the behavior of those around them. Kalianget village is still implementing open defecation in the river. This is due to the low level of public knowledge which is triggered by the lack of role of healthy officer regarding counseling about healthy latrines. The purpose of this study is to determine knowledge about healthy latrines and healthy officer with open defecation in Kalianget Village, Seririt District, Buleleng Regency. The research was case control method with 90 families as samples. The results of obtained by the respondents' knowledge were the highest in the bad category, namely as many as 34 people (24.6\%). With the role of health officer related to open defecation was highest in the good category, namely 39 people (43.3\%). and the behavior of respondents related to open defecation and not open defecation at the same point, namely as many as 45 people (50\%). The value of asymp.sig 0,000<0.05 was obtained where the results showed relationship between the level of knowledge and the role of healthy officer with public open defecation behavior. Suggestions that can be given are to conduct socialization activities about healthy latrines and it is hoped that people who don't have latrines to share with their closest neighbors.
\end{abstract}

Keywords: Knowledge, Role of Health Officers, BABS

\section{PENDAHULUAN}

Perilaku BABS atau juga disebut dengan Open Defecation Free $(O D F)$ merupakan salah satu perilaku hidup yang tidak sehat. Berbagai penyakit yang menjadi akibat dari sanitasi buruk di Indonesia antara lain penyakit diare sebesar $72 \%$, kecacingan $0,85 \%$, hepatitis A $0,57 \%$, scabies $23 \%$, trakhoma $0,14 \%$, hepatitis E $0,02 \%$ dan malnurisi 2,5\%.2 Sebagai upaya untuk meningkatkan persentase angka kesakitan maupun kematian akibat sanitasi yang buruk ${ }^{1}$. Di Indonesia, diperkirakan jumlah orang yang masih melakukan BABS berkisar antara 29 juta hingga 31 juta orang, menempatkan Indonesia pada tiga negara teratas dengan beban BABS 2. BABS adalah suatu tindakan membuang kotoran atau tinja di ladang, hutan, semak-semak, sungai, pantai atau area terbuka 
lainnya dan dibiarkan menyebar mengontaminasi lingkungan, tanah, udara, dan air ${ }^{3}$.

Peran yang paling dominan dalam sebuah keluarga adalah kepala keluarga ${ }^{4}$. Kepala keluarga memiliki peran dalam sebuah keluarga dan masyarakat, karena dianggap dapat mempengaruhi individu dalam sebuah keluarga yang bermasalah, selain itu kepala keluarga merupakan anggota kelompok sosialnya dan anggota masyarakat dari lingkungannya yang diakui keberadaannya ${ }^{5}$.

Berdasarkan data $O D F$ Baseline Kecamatan Seririt, Dinas Kesehatan Kabupaten Buleleng, 20 Desa yang tercatat hanya 3 Desa yang $O D F$ yaitu Desa Umeanyar, Seririt, dan Kalisada. Berdasarkan data dari Puskesmas Seririt I, Desa kalianget merupakan jumlah penduduknya dominan tidak memanfaatkan jamban dengan baik, yaitu Desa Kalianget sebanyak 85 KK, Joanyar 32 KK, Tangguwisia 14 KK, Sulanyah 5 KK, Pengastulan 15 KK, dan Desa Bubunan sebanyak 27 KK. Desa Kalianget yang terdiri dari 906 KK dengan 3,753 penduduk dan jumlah KK belum memiliki jamban sehat sebanyak 85 KK yang dijadikan sebagai dasar penelitian ini. Untuk meningkatkan angka penggunaan jamban sehat petugas kesehatan melakukan pengupayaan dengan pemicuan 5 pilar STBM yang bertujuan untuk pembentukan perubahan perilaku masyarakat dan menumbuhkan rasa malu masyarakat BABS dengan memberikan edukasi menggunakan media berupa pamflet, video dan raplika yang merupakan manipulasi media asli dengan menggunakan media buatan. Oleh sebab itu penelitian memilih Desa Kalianget dan tertarik untuk mengambil penelitian tentang bagaimana hubungan pengetahuan tentang jamban sehat dan peran petugas kesehatan dengan perilaku BABS di Desa Kalianget, Kecamatan Seririt, Kabupaten Buleleng.

Tujuan penelitian ini dilakukan untuk mengetahui hubungan pengetahuan tentang jamban sehat dan peran petugas kesehatan dengan perilaku BABS di Desa Kalianget, Kecamatan Seririt, Kabupaten Buleleng. 


\section{METODE PENELITIAN}

Jenis penelitian yang dipergunakan adalah wawancara dengan rancangan kasus - kontrol (case control) ${ }^{6}$ yaitu menganalisa antara variabel bebas berupa pengetahuan, peran petugas kesehatan dan variabel terikat yaitu perilaku BABS. Teknik pengambilan sampel dalam penelitian ini menggunakan teknik total purposive sampling. Sampel terpilih dikelompokkan menjadi dua yaitu : 45 sampel sebagai kelompok kasus dan 45 sampel sebagai kelompok kontrol .

Teknik pengumpulan data dengan wawancara menggunakan kuesioner. Pada penelitian ini menggunakan uji analitik chi square dengan kemaknaan $p<0,05$. Interpretasi hasil dilakukan jika nilai korelasi $p=0,000$ yang diartikan ada hubungan antara variabel bebas dengan variabel terikat, serta dilakukan perhitungan $C C$ untuk mengetahui keeratan hubungan antara kedua variabel ${ }^{7}$.
HASIL DAN PEMBAHASAN

\section{A. Hubungan \\ tingkat \\ pengetahuan tentang jamban sehat dengan perilaku buang air besar sembarangan Di Desa}

Kalianget Kecamatan Seririt Kabupaten Buleleng

Berdasarkan hasil inpretasi bahwa responden yang memiliki pengetahuan baik dengan perilaku masih BABS sebanyak 0 responden $(0 \%)$. Selanjutnya pengetahuan responden yang baik dengan perilaku tidak BABS (Buang Air Besar Sembarangan) sebanyak 33 responden (100\%). Pengetahuan sedang yang dimiliki responden terhadap perilaku masih BABS sebanyak 11 responden (47,8\%). Sedangkan dengan perilaku tidak BABS sebanyak 12 responden (52,2\%). Pengetahuan responden yang buruk terhadap jamban sehat dipengaruhi oleh perilaku masih BABS sebanyak 34 responden (100\%) dan perilaku tidak BABS sebanyak 0 responden $(0 \%)$. Dengan hasil uji chis quare diperoleh nilai $\mathrm{p}$ $=0,000$ bahwa ada Hubungan Tingkat Pengetahuan Jamban Sehat Dengan Perilaku Buang Air Besar Sembarangan Di Desa Kalianget, 
Kecamatan Seririt, Kabupaten

Buleleng. Berdasarkan hasil wawancara, masih terdapat responden yang tidak mengetahui syarat jamban yang sehat. Pengetahuan merupakan hasil dari tahu, dan ini terjadi setelah orang melakukan pengindraan terhadap suatu objek tertentu setelah orang melakukan pengindraan terhadap suatu obyek tertentu. Sebagaian besar pengetahuan manusia diperoleh melalui mata telinga 6 .

Dari hasil wawancara dengan kepala Dusun bantuan untuk membangun jamban belum ada dari pihak desa, hal ini dikarenakan belum adanya air bersih di rumah warga. Namun berdasarkan hasil wawancara bantuan untuk membangun sumur bor sudah diproses dan sumur bor akan direalisasikan pada bulan Desember tahun 2021 untuk warga yang belum memiliki air bersih di rumah. Penelitian ini sejalan dengan penelitian yang dilakukan ${ }^{8}$ yang menyatakan terdapat hubungan antara ketersediaan air bersih dengan perilaku BABS, yang dimana responden yang tidak memiliki air bersih di rumah lebih banyak menggunakan sumber air bersih dari air sungai, dan beberapa responden membeli air bersih jerigenan milik tetangga.

Hasil penelitian ini sesuai dengan pendapat ${ }^{9}$ yang menjelaskan bahwa menurut teori Green, salah satu faktor yang mempengaruhi perilaku kesehatan seseorang yaitu faktor predesposisi yang meliputi pengetahuan. Pendidikan merupakan faktor yang berpengaruh dalam membentuk pengetahuan, sehingga dapat disimpulkan bahwa semakin tinggi tingkat pendidikan seseorang maka akan semakin sadar dan peduli terhadap kebersihan diri dan lingkungannya.

\section{B. Hubungan peran petugas kesehatan dengan perilaku buang air besar sembarangan}

Berdasarkan hasil penelitian analisis data menggunakan uji chis quare diperoleh nilai $\mathrm{p}=0,000$ bahwa ada Hubungan Peran Petugas Kesehatan Dengan Perilaku Buang Air Besar Sembarangan Di Desa Kalianget, Kecamatan Seririt Kabupaten Buleleng Tahun 2021. Untuk melihat kuat lemahnya hubungan dilihat dari nilai coefficient kontigensi (CC) yaitu 
0,674. Nilai tersebut menunjukkan hubungan yang kuat antara variabel peran petugas kesehatan dengan perilaku BABS. Hasil penelitian ini sejalan dengan teori Lawrence Green yang menyatakan bahwa perilaku dipengaruhi salah satunya oleh faktor pendukung yaitu faktor yang terwujud dalam perilaku yang merupakan kelompok referensi dari perilaku masyarakat, salah satunya petugas kesehatan.

Peran petugas kesehatan adalah suatu kegiatan yang diharapkan dari seorang petugas kesehatan yang memberikan pelayanan kesehatan kepada masyarakat untuk meningkatkan derajat kesehatan masyarakat. Tenaga kesehatan memiliki peranan penting untuk meningkatkan kualitas pelayanan kesehatan yang maksimal kepada masyarakat agar masyarakat mampu untuk meningkatkan kesadaran, kemauan, dan kemampuan hidup sehat sehingga akan terwujud derajat kesehatan yang setinggi-tingginya sebagai investasi bagi pembangunan sumber daya manusia yang produktif secara sosial dan ekonomi serta sebagai salah satu unsur kesejahteraan umum ${ }^{10}$

\section{SIMPULAN}

Berdasarkan hasil penelitian dan pembahasan dapat disimpulkan ada hubungan tingkat pengetahuan tentang jamban sehat dengan perilaku buang air besar sembarangan BABS dengan menunjukkan hubungan yang kuat dan ada hubungan peran petugas kesehatan dengan perilaku buang air besar sembarangan (BABS) di Desa Kalianget, Kecamatan Seririt dengan menunjukkan hubungan yang kuat.

\section{SARAN}

Upaya yang dapat dilakukan bagi petugas kesehatan dengan mengadakan kegiatan sosialisasi dan penyuluhan tentang jamban sehat 1 (satu) bulan sekali serta upaya-upaya untuk mengurangi bahaya tersebut, sehingga dapat meningkatkan pengetahuan tentang jamban sehat dengan perilaku BABS. Upaya yang dilakukan oleh masyarakat yang belum memiliki dan menggunakan jamban sehat diharapkan menumpang sementara dengan saudara maupun tetangga terdekat, namun kedepannya harus memiliki dan menggunakan jamban sehat serta 
meningkatkan wawasan pengetahuan mengenai pentingnya kepemilikan jamban sehat di rumah tangga.

\section{DAFTAR PUSTAKA}

1. Nurjazuli. HUBUNGAN PENGETAHUAN, SIKAP

BAB, DAN KEPEMILIKAN

SEPTIC TANK DENGAN

STATUS ODF (OPEN

DEFECATION FREE) DI

KECAMATAN CANDISARI

KOTA SEMARANG. $J$.

Kesehat. Masy. (2018).

2. BPS, N. B. Susenas (National

Socio Economic Survey). (2016).

3. Murwati. Faktor Host Dan

Lingkungan Yang

Mempengaruhi Perilaku

Buang Air Besar

Sembarangan/Open

Defecation. (2020).

4. Andreas, H. Faktor-Faktor

Yang Mempengaruhi Perilaku

Keluarga dalam Menggunakan

Jamban di Desa Tawin

Kecamatan Teluk Kota

Ambon. (2014).
5. Kurniawati, T. Buku Ajar

Kependudukan dan Pelayanan

KB. Jakarta: EGC. (2015).

6. Notoadmodjo, S. Promosi

Kesehatan dan Perilaku

Keehatan. Rineka Cipta.

Jakarta. (2012).

7. Sugiyono. Metode Penelitian

Kuantitatif Kualitatif dan

$R \& D$. (Alfabeta, 2012).

8. Kamria, Chaeruddin \&

Darmawan, S. Faktor-Faktor

Yang Mempengaruhi

Masyarakat Terhadap

Pemanfaatan Jamban Keluarga

Di Desa Bontotallasa Dusun

Makuring Kabupaten Maros.

J. STIKES Nani Hasanuddin

Makassar 3 nomor 1, 99-102

(2013).

9. Notoatmodjo, S. Promosi

Kesehatan dan Ilmu Perilaku.

Jakarta:Rineka Cipta. (2007).

10. Maulana. Evaluasi Penyediaan

Layanan Kesehatan di Daerah

Pemekaran Dengan Metode

CIPP (Studi pada Pemerintah

Daerah Kabupaten Tana

Tidung). (2013). 